\title{
SELECTED ASPECTS OF ANGIOGENSIS IN HAEMATOLOGICAL MALIGNANCIES
}

\author{
Patrycja SUJKA-KORDOWSKA, Agnieszka MALIŃSKA, Maciej ZABEL \\ Department of Histology and Embryology, \\ Poznań University of Medical Sciences, Poland
}

DOI: $10.2478 / \mathrm{v} 10052-011-0002-5$

\begin{abstract}
Summary: It is well established that angiogenesis is necessary in solid tumours development. Interesingly, the role of angiogensis in haematological malignancies has been also recognized. Recent publicationts indicate that microvessel density in bone marrow and angiogenic factors like endoglin, placental growth factor and cyclooxygenase 1 are increased in lymphoproliferative disorders and suggest that angiogensis is a part of pathomechanism of these malignancies. However, it has not been identified how angiogenesis can be involved in progression of haematological disorders. There is a strong need for further investigations in this area, since antiangiogenic therapy is a potential adjunct to conventional therapy of lymphoproliferative disorders.
\end{abstract}

Key words: angiogenesis, acute lymphoblastic leukemia, acute myeloid leukamia, angiogenic factors, microvessel density

\section{ANGIOGENESIS - DEFINITION, MECHANISM AND SIGNIFICANCE}

Development of blood vessels represents an indispensable condition for body development and differentiation during embryogenesis. Therefore, in vertebrata organ of circulation develops first [12]. Also during extrauterine life development of blood vessels carries an immense significance for a normal body functioning. Abnormal blood vessels as well as disturbances in vascular structure and function may cause several diseases or even be lethal [14].

Development of new blood vessels includes three processes: vasculogenesis, angiogenesis and arteriogenesis. 
The first of them is typical for embryonal stage and involves formation of blood vessels from endothelial stem cells, haemangioblasts, developing in haematogenic islands of embryonal yolk sac. This results in development of a primordial vascular plexus in the third week of embryogenesis in regions not supplied with blood vessels [7, 73]. In the extrauterine life blood vessels do not develop by vasculogenesis [73]. Excceptions include certain pathological conditions, such as neoplastic diseases, injured cornea or ischaemia of lower extremities, in which development of new blood vessels is noted with involvement of endothelial precursor cells [59].

In subsequent stages of foetal development blood vessels develop due to angiogenesis (called also neovascularisation) and arteriogenesis. arteriogenesis involves transformation of existing collateral arterioles into functional arteries due to thickening of their muscle layer which provides the blood vessels with vasomotoric properties [41]. Transformation of small blood vessels yields conducting arteries of a 20 -fold higher diameter. Arteriogenesis occurs also in the extrauterine life e.g., in a mature ischaemic and anoxic heart [95].

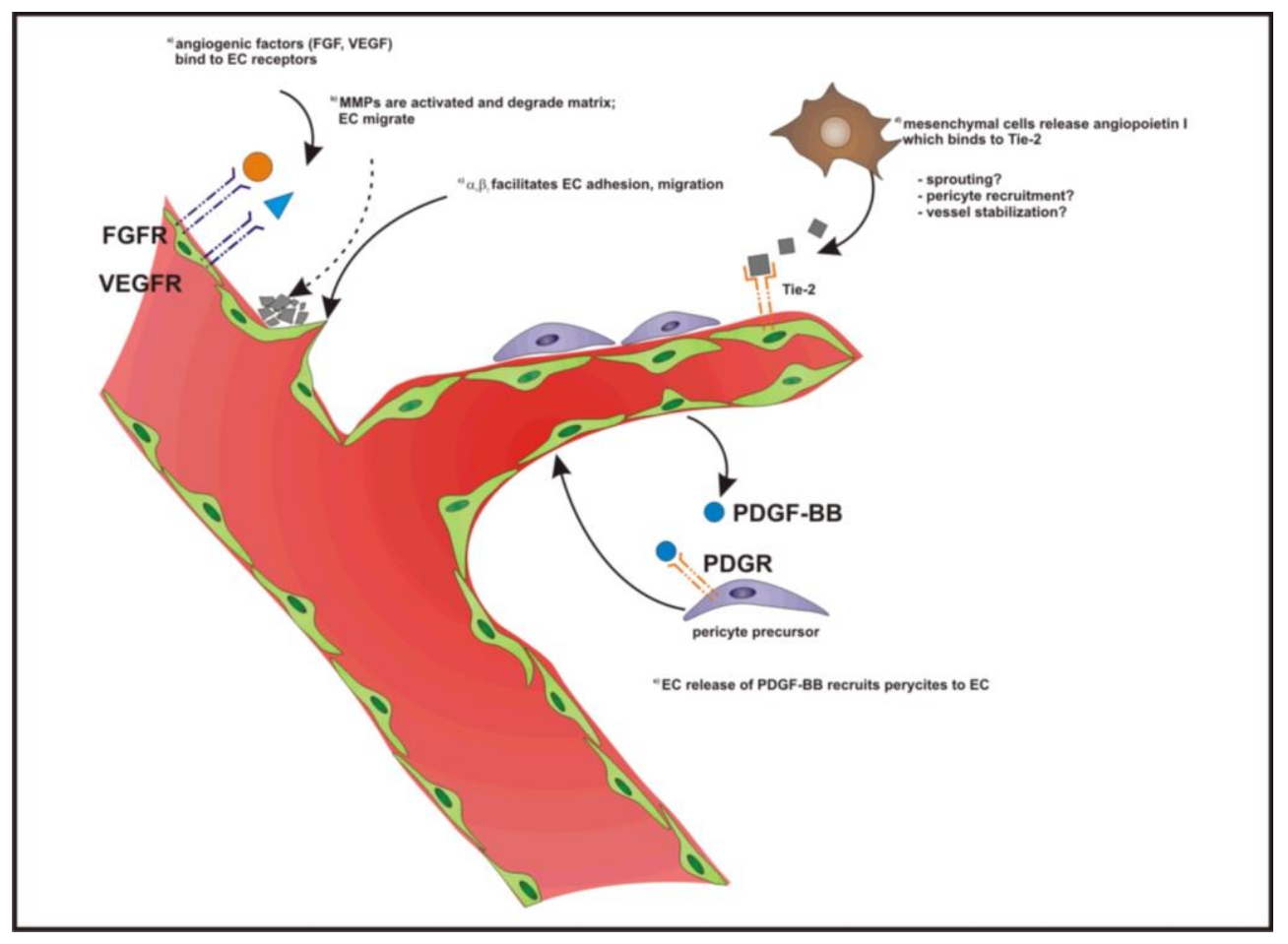

FIGURE 1. The steps of blood vessels formation

In turn, angiogenesis represents a process in which new blood vessels develop from already existing ones, which takes place due to budding of parietal 
endothelium cells and endothelial cells of capillary ends. Angiogenesis represents the main way if blood vessel formation in extrauterine life. In such cases it is typical of specific physiological situations. It develops in certain stages of menstruation cycle: during remidelling of uterine mucosa and formation of corpus luteum. It is also indispensable during implantation of embryo in mucometrium and formation of placenta [85]. Physiological angiogenesis is observed also in intestinal mesentery and during endochondral ossification [29]. Process of neovascularization accompanies also development of granulation tossue during wound healing [97]. Angiogenesis represents also a key component in pathogenesis of several diseases. It plays a significamt role in development of chronic inflammation: psoriasis, rheumatoid arthritis or asthma [15, 24]. It constitutes one of elements engaged in development and course of gatsroenterological diseases (Crohn's disease, ulcerative colitis), cardiological diseases (arteriosclerosis, myocardial ischaemia, cyanotic cardiac defects, neuroinfections and diabetes mellitus) [14]. The process is lalso to formation of adipose tissue, which suggests its involvement in development of obesity [11]. Without doubt, angiogenesis plays an immense role in development of neoplastic diseases, determining both size of the tumour and development of metaastases [24].

Angiogenesis represents a complex, multi-stage process [14]. At the first stage blood vessels become more flaccid and vascular endothelial cells become activated due to various physical and humoral factors (hypoxaemia, hypoglycaemia). This induces release and binding of pro-angiogenic factors to their receptors of the surface of endothelial cells. A principal role in initiation of angiogenesis is played by proteins of VEGF family: vascular endothelial growth factor and fibroblast growth factor (FGF). Due to action of locally activated proteolytic enzymes, such as metalloproteinases (MMP), basement membrane providing support for endothelial cells and extracellular matrix (ECM) undergo degradation. This provides an indispensable condition for penetration of endothelial cells to new locations. In addition, proteolysis of ECM yields products inducing release of ECM-trapped growth factors and compounds of chemotactic activity, promoting the subsequent migration of endothelial cells. At this stage adhesion molecules are active, located at the surface of endothelial cells (integrins $\alpha_{v} \beta_{3}, \alpha_{v} \beta_{5}$, selectin $E$ ), which interact with specific components on extracellular matrix (vitronectin, fibronectin, laminin) [22]. In parallel, endothelial cells proliferate. At rest, cell cycle of endothelial cells exceeds 1000 days but during angiogenesis it becomes abbreviated to 5 days. Divisions of endothelial cells assure continuity of a blood vessel and development of its intima. At the subsequent stage vascular lumen develops: elongated pipe-like structure are formed which anastomose at ends forming capillary loops. Basement membrane becomes produced also. Development of a blood vessel of a full value requires recruitment and binding of adventitia cells (pericytes) and, in cases of large vessels, also of smooth muscle cells. This stage is controlled by platelet-derived growth factor 
(PDGF) [77]. At the late phase of angiogenesis, endothelial cells become linked to the surrounding mesenchymal cells and stable cellular and biochemical interactions are formed, in which angiopoetins and receptors Tie 1 and 2 play principal role [54].

\section{CONTROL OF ANGIOGENESIS}

Angiogenesis represents a complex process, requiring engagement of several factors. Initiation of the process requires cooperation of: 1) various cell types, 2) components of extracellular matrix and 3) compunds which stimulate or inhibit angiogenesis [84]. It should be mentioned that the latter group of factors plays a key role. Angiogenesis is thought to be controlled by a balanced expression of factors manifesting pro- and anti-angiogenic character and in healthy adult individuals the balance is shifted toward the latter factors [33]. In turn, mobilization of angiogenetic programme is induced by augmented expression of stimulators and/or a decreased expression of inhibitors. Acquisition of angiogenic phenotype used to be termed the angiogenic switch [33].

The factors of pro-angiogeniuc character include also a number of cytokines and mediators, which stimulate growth and proliferation of endothelial cells, degrade extracellular matrix or induce maturation of blood vessels.

\section{FAMILY OF VASCULAR ENDOTHELIAL GROWTH FACTOR (VEGF)}

Vascular endothelial growth factor (VEGF) plays a key role in initiation of physiological and pathological angiogenesis, lymphangiogenesis and also vasculogenesis. It was discovered in 1983 by Dvorak and described as a factor affectong vascular permeability [79]. VEGF is the most powerful and the most specific factor of endithelial cell growth. The family of VEGF consists of VEGF-A (habitually termed VEGF), VEGF-B, VEGF-C, VEGF-D, VEGF-E, VEGF-F and placenta growth factor (PIGF) [90]. The factirs bond to their specific receptors VEGFR-1, VEGFR-2 and VEGFR-3 on endothelial cells, as well as also to neuropilin 1 and 2 (Nrp-1 and Nrp-2), representing receptors for semaphorins, factors of a directed axon growth. Interactions between molecules of VEGF family and their receptors are complex. Depending on the type of linkage formed, the interactions initiate distinct pathways, as illustrated in Figure 2. 


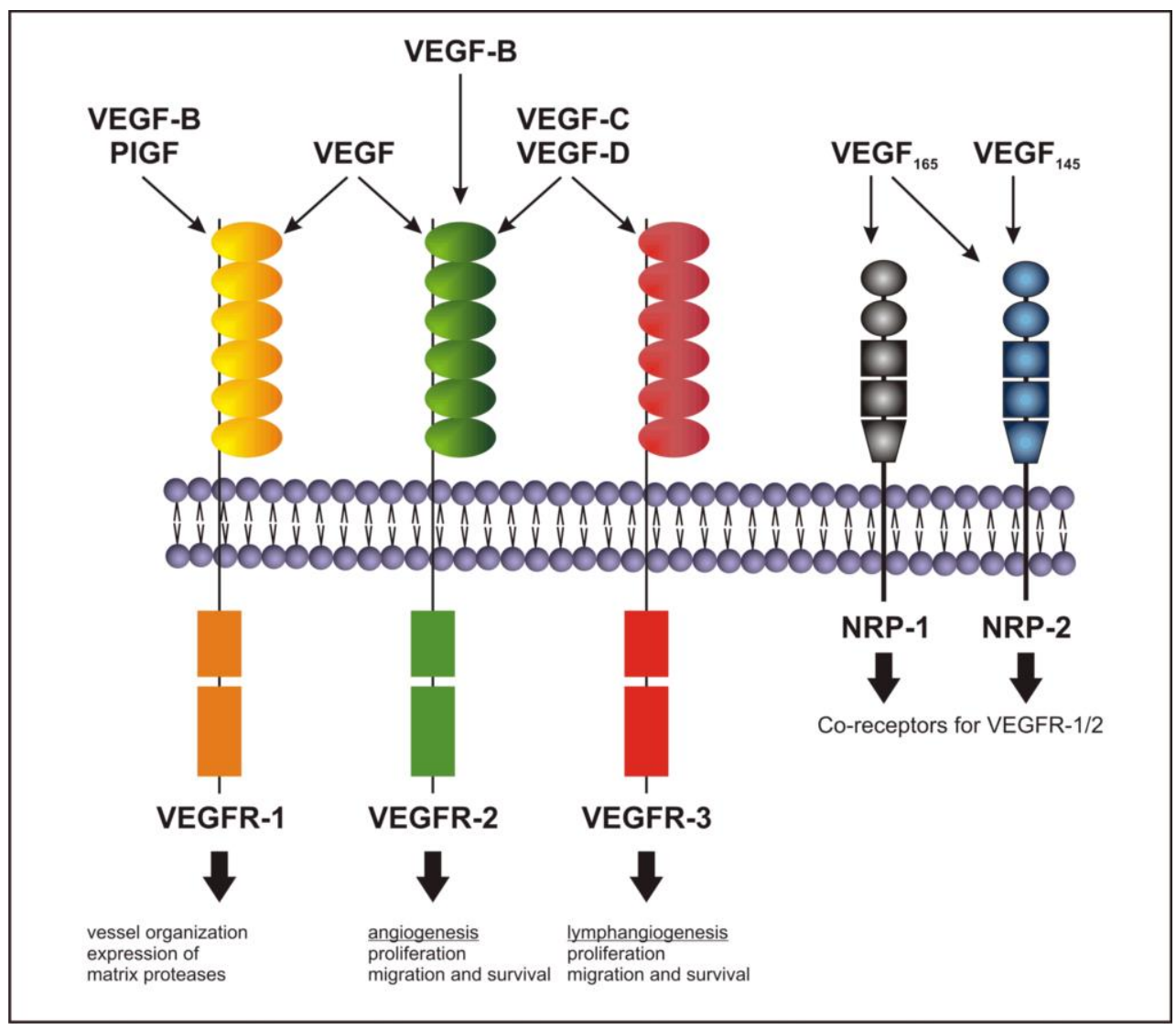

FIGURE 2. Interactions between members of VEGF family and their receptors. Specific binding ligand/receptor causes different effect on endothelial cells

VEGF gene contains 8 exons. Its aternate splicing during transcriptions yields at least 6 isoforms of the protein: $\mathrm{VEGF}_{121}, \mathrm{VEGF}_{145}, \mathrm{VEGF}_{165}, \mathrm{VEGF}_{183}$, $\mathrm{VEGF}_{189}$ andi $\mathrm{VEGF}_{206}$, of which isoforms $\mathrm{VEGF}_{121}, \mathrm{VEGF}_{165}, \mathrm{VEGF}_{189}$ are most frequently produced by several cell types [23]. In some isoforms, presence of heparin-binding domains favours formation of VEGF - proteoglycan compounds in extracellular matrix, which promotes cummulation of the molecules in ECM.

Synthesis of VEGF is induced in conditions of anoxia by HIF (hypoxia inducible factor). In such a situation, inhibition takes place of oxygen-dependent constitutive HIF- $1 \alpha$ degradation. HIF binds to the promoter of VEGF gene and stimulates its transcription [49].

Effect of VEGF on angiogenesis is compregensive and manifests in several areas. It induces proliferation, growth, migration of endothelial cells and affects their spatial organization during formation of a blood vessel [23]. It increases permeability of blood vessels, i.a., due to formation of gaps between the cells [6]. 
Activating nitrogen oxide synthase (eNOS) and linked to it production of nitrigen oxide it induces vasodilation during preliminary stages of angiogenesis [34]. It also stimulates expression of proteases engaged in degradation of extracellular matrix [64]. Moreover, it activates expression of anti-apoptotic factors, acting as a factor which secures survival of endothelial cells [9].

Several factors which stimulate angiogenesis are thought to act indirectly, thrpugh induction of VEGF expression. Such factors include, i.a., transforming growth factor (TGF $\beta$ ), platelet-deroved growth factor (PDGF), epithelial growth factor (EGF), interleukins $1 \beta$ and 6 [82]. It was also claimed that nitrogen oxide may stimulate expression of VEGF, forming in this way an autocrine loop with VEGF [74].

\section{PLACENTAL GROWTH FACTOR (PIGF)}

Placental growth factor (PIGF), belonging to VEGF family was discovered in 1991 by Graziella Perscio [53]. In parallel, PIGF was found to bind to receptor 1 of VEGF. Moreover, in mice with no PIGF gene the process of angio- and arteriogenesis was found to be significantly inhibited despite high levels of VEGF [52].

PlGF gene is located on the long arm of chromosome 14, in locus 24 and it encompasses 7 exons. Amino acid sequence of PlGF i on $42 \%$ identical with sequence of VEGF and PIGF demonstrates a high structural similarity to VEGF [53]. PlGF functions as a dimer. Until now, its 4 isoforms were identified, differing in their number of amino acids: PlGF-1 $\left(\mathrm{PlGF}_{131}\right)$, PlGF-2 $\left(\mathrm{PlGF}_{152}\right)$, PlGF-3 $\left(\mathrm{PlGF}_{203}\right)$ and PlGF-4 $\left(\mathrm{PlGF}_{224}\right)$, formed due to an alternate splicing. The isoforms manifest also affinity to other receptors. PlGF-1, PIGF-3 and PlGF-4 bind to receptor 1 of VEGF, while PIGF-2 in addition binds to neuropilin 1 and 2 . Moreover, isoforms 2 and 4, which carry heparin-binding domains, may bind to proteoglycans of ECM and be stored there.

At first, presence of PlGF was demonstrated in placenta, in which it was supposed to contrl growth and differentiation of trophoblast [53]. Immunocytochemical studies deminstrated presence of PIGF in media of large placental blood vessels. Studies demonstrating expression of PlGF in early stages of embryogenesis in mice suggest its involvement in initiation and coordination of vascularization [2]. PlGF is present also in the heart, lungs, thyroid gland, skeletal muscles and adipose tissue [66].

Placental growth factor represents a positive regulator of angiogenesis. It is thought to stimulate the process by a few mechanisms [Figure 4]:

- by a direct effect on endothelial cells through VEGFR-1 [52],

- by separation of VEGF from receptor 1, in parallel allowing interaction of VEGF with VEGFR-2 [49], 
- by sensitization of cells to activity of VEGF-VEGFR-2 through interaction of PIGF-VEGFR-1 [96],

- by recruitment of monocytes/macrophages engaged in the process of vascular growth [16]

- through mobilization of haemopoetic progenitor cells from bone marrow [16].

Placental growth factor may also act as an inhibitor of angiogenesis. This happens when PlGF forms a heterodimer with VEGF. Such a complex manifests 20 - to 50-fold less pronounced angiogenesis-stimulating effect than that induced by VEGF homodimer. Experiments on animal models demonstrated that PIGF may block angiogenesis stimulated by VEGF by decreasing the pool of VEGF homodimers [98].

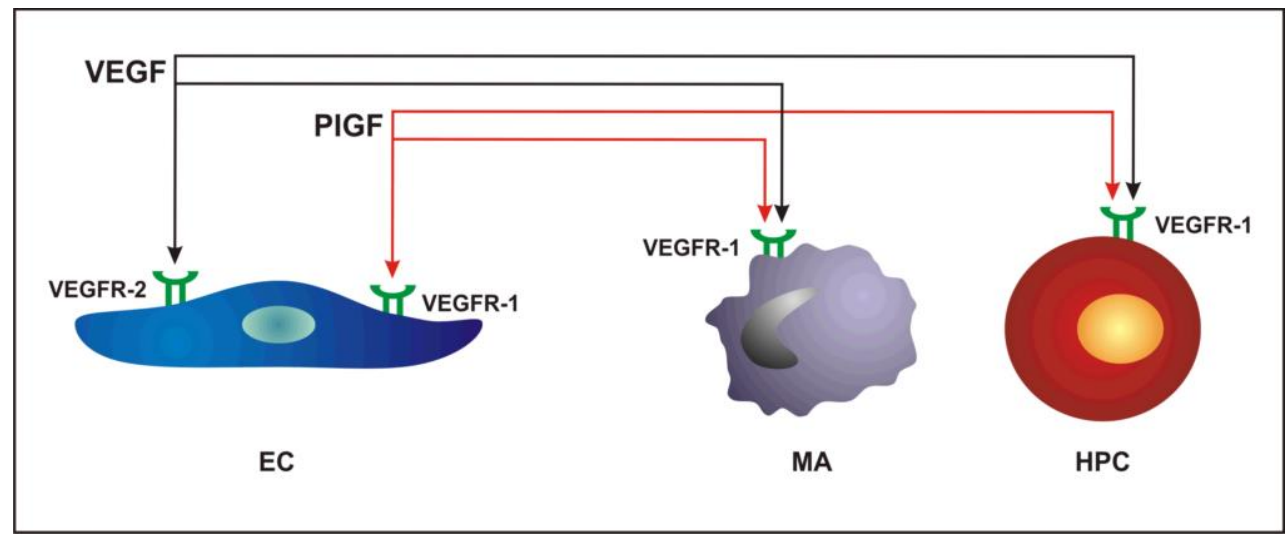

FIGURE 3. VEGF and PIGF dependent angiogenesis can be initiated by binding to VEGFR-1 and VEGFR-2 receptors, both present on endothelial cells (EC). VEGFR-1 is also present on macrophages (MA) and haematopietic progenitor cells (HPC).

\section{ENDOGLIN (ENG) / CD105 ANTIGEN}

Endoglin/CD105 represents a homodimeric transmembrane protein of 180 $\mathrm{kDa}$ molecular weight. It was identified in 1985 by the team of Latarte [30]. The gene of CD105 is located on chromosome 9q34 and contains 14 exons. The protein contains short cytoplasmic and transmembrane domains and an extensive extracellular domain, containing RGD (arginine-glycine-aspartic acid) motif. It undergoes $\mathrm{N}$ - and $\mathrm{O}$-glycosylation. Two isoforms of endoglin are known, differing in cytosolic terminus: L-CD105 (633 aa, 47 forms the intracellular domain) and SCD105 (600 aa, 14 at the cytoplasmic terminus) [8]. The form $\mathrm{L}$ is suggested to prevail. 
Endoglin is thought to represent a protein engaged in angiogenesis, maturation of blood vessels and maintenance of body homeostasis. CD105 manifests a pronounced expression in endothelial cells at the early stages of embryogenesis (4th-8th week) and during formation of septa and valves in myocardium [69]. Absence of endoglin in mouse embryos is lethal [45]. In human tissues CD105 manifests expression mainly in cells of vascular endothelium and of stroma [26] and in placental syncytiotrophoblast [89]. Its poor exprewssion is noted also in activated monocytes, macrophages, erythrocyte precursors, fibroblasts, mesangial cells, dendritic cells and melanocytes [26, 18]. Endoglin level manifests positive correlation with the extent of proliferation of human umbillical vein endothelial cells (HUVEC) and with expression of proliferation markers, Ki-67 or cyclin A [27]. CD 105 manifests an overexpression in endothelial cells of newly formed blood vessels of neoplastic tumours [27]. It is present also in immature blood vessels and blood vessels undergoing reconstruction.

Endoglindemonstrates an extensive homology with receptor III (betaglycan) of tramsforming growth factor $\beta$ and it functions as its adjuvant receptor, modulating cell response to TGF $\beta$ action [17]. It is able to bind TGF $\beta 1$ and 3 (but not TGF $\beta 2$ ) and other ligands, e.g. activin A or bone morphogenetic protein (BMP) 7 and 2 [17]. It was demonstrated that CD105 in order to bind the ligand it requires presence of TGF $\beta$ receptor II. Moreover, ENG interacting with TGF $\beta$ receptor I and II controls degree of their phosphorylation and in this way affects their ability to transmit signals [30]. However, it may function independently on cell surface.

Mechanism of endoglin functioning as a molecule of pro-angiogenic character has not been fuly recognised. Endoglin seems to stimulate TGF $\beta /$ ALK1 signalling pathway, which induces phosphorylation of Smad 1 and 5 molecules which, in the result, promotes proliferation and migration of endothelial cells to the site of blood vessel formation [31]. In parallel, it indirectly inhibits the Smad 2 and 3 phosphorylating TGF $\beta /$ ALK5 pathway, responsible for inhibition of cell divisions.

Endoglin is also suggested to represent a component of the pathway activating synthesis of nitrogen oxide and a modulator of cyclooxygenase 2 (COX2) and in this way, indirectly, it controls tension of blood vessel wall [38]. Probably, it influences also activation of expression involving molecules of antiapoptotic activity in vascular endothelium cells during neoplastic angiogenesis [44].

Involvement of endoglin in neoplasia of blood vessels in a neoplastic tumour has not been confirmed but in vitro an elevated expression level of the protein was demonstrated in metastases of prostate tumours and ovarian cancer [48, 61]. Moreover, a deficit in the molecule in CD105+/- mice, carrying Lewis'es lung tumour, was linked to a significantly decreased blood vessel supply to the tumour and size of the tumour [19]. Evaluation of microvessel density (MVD) in a tumour 
using anti-CD105 antibodies is thought to provide a good tool to evaluate prognosis [43].

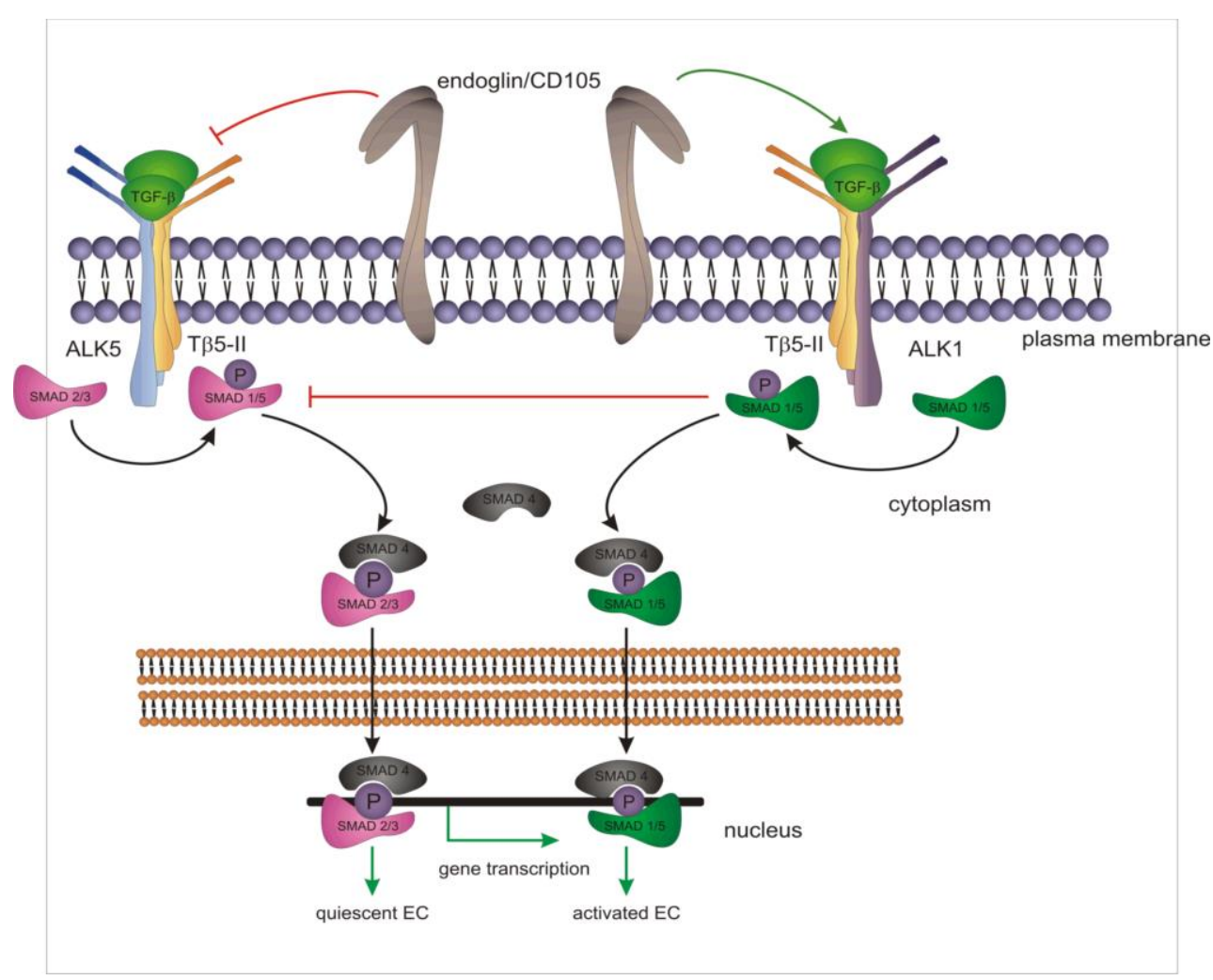

FIGURE 4. A hypothetic role of endoglin/CD105 in TGF- $\beta$ /ALK5 and TGF- $\beta / A L K 1$ signalling pathways in endothelial cells.

\section{CYCLOOXYGENASE 1 COX-1/PTGS1}

Cyclooxygenase (termed also synthase of prostaglandins $\mathrm{G} / \mathrm{H}$ ) is a key enzyme catalyzing transformation of arachidonic acid (AA) to prostaglandins $\mathrm{G}_{2}$ and $\mathrm{H}_{2}$, engaged, i.a., in control of inflammation, fever and pain [91]. Two isoforms of the enzyme include COX-1 and COX-2. Expression of COX-1 is constitutive, while COX-2 is activated by stimulators of inflammation and proliferation [86].

Studies on cyclooxygenase 1 have continued since 1970-ties but sequence of human COX-1 was determined in 1989 roku [100]. Gene of the enzyme is located on the long arm of chromosome 9 in locus 32 and it includes 11 exons.The 
produced protein contains 576 amino acids and manifests molecular weight of 70 $\mathrm{kDa}$.

COX-1 undergoes expression in almost all types of human tissues. A particularly high level of the protein is present in endothelium of blood vessels, smooth muscle cells, seminal vesicles, blood platelets, monocytes, mesothelial cells and nephron collecting tubules [91]. COX-1 stimulates synthesis of PGs required to maintain homeostasis (i.a., in alimentary tract or in haemostasis). Despite the claims that PTGS1 is permanently present in tissues, induction of the enzyme was observed in several cell lines, in which cells differentiate (i.a., in endothelial cells) [57]. Also, augmented expression of COX-1 was demonstrated in acute cholecystitis in guinea pigs [10]. Moreover, elevated level of the enzyme was documented in some tumours (breast cancer, oesophageal adenocarcinoma, cancer of uterine cervix) as well as during development of polyps in large intestine [75, $46,58]$. The fact was explained by involvement of COX-1 in the process of angiogenesis.

Role of cyclooxygenase in angiogenesis is far from clear. The protein seems to be engaged in formation of blood vessels. The data stem mainly from experimental models. This function of COX-1 is confirmed mainly by the fact that selective inhibitors of COX-1 block also neovascularization [58, 75, 76, 46]. Moreover, expression of PTGS1 expression was found to correlate with factors of pro-angiogenic character: VEGF, bFGF, angiopoetins 1 and 2 [46, 58, 76]. Moreover, release of the factors was found to be blocked by inhibitors of COX-1. The mechanism through which COX-1 controls angiogenesis has not been recognized. Probably it is linked to engagement of the enzyme in synthesis of prostaglandins, which significantly affect formation of blood vessels [92]. COX-1 probably participates in one of the terminal stages of angiogenesis, i.e. formation and elongation of vascular lumen [92].

\section{ANGIOGENESIS AND NEOPLASTIC PROCESS}

A crucial step in tumour biology involved the thesis, posed by the Americal scientist, Judah Folkman in 1971, related to significance of angiogenesis for development of tumours [25]. At the first stage of tumour progression, it represents an accumulation of around one million cells of not more than $1-2 \mathrm{~mm}^{3}$ in size. At the phase of growth and development, the tumour is independent of vascular supply since oxygen and nutrients rich tumour cells by diffusion. On the other hand, at later stages of carcinogenesis tumour stimulates formation of new blood vessels since the till now available manner of tumour supply becomes insufficient and in its central portion necrosis may develop. In parallel, the tumour takes advantage of the vascular network to spread throughout the body by development of metastases [25]. Reports of recent years indicate that the newly 
formed blood vessels play additional functions: they provide source of growth factors, cytokines and hormones, which stimulate tumour growth [71], as well as manifest proteolytic activity which promotes tumour invasiveness [13]. The process of angiogenesis, in physiological conditions strictly controlled, in a neoplastic disease by-passes control mechanisms. A stable production develops of factors, manifesting pro-angiogenic activity while expression of neovascularization inhibitors becomes reduced: the angiogenic switch becomes eliminated [33].

The strict relationship between angiogenesis and tumour development provided a starting point for studies on a new manner of treating neoplastic diseases, the anti-angiogenic therapy. The idea surfaced already within a year after the critical discovery of Folkman. After over 30 years later, the first drug blocking tumour angiogenesis (Avastin/bevacizumab) became accepted for clinical use [36].

\section{ANGIOGENESIS IN SOLID TUMOURS}

A pronounced angiogenesis is observed in a number of solid tumours, both in adults and in children. In adults intensity of blood vessel formation manifests a strict correlation with clinical advancement of a disease, prognosis and frequency of metastasis development [56]. The process is monitored mainly by evaluation of expression related to pro-angiogenic type factors. Studies in vitro and in vivo confirm elevated levels of vascular endothelial growth factor and its receptors in breast tumours, colorectal cancer, oesophageal cancer, cancers of gallbladder, pancreas or prostate [51, 80, 5, 67, 88]. Elevated levels are also noted of other molecules participating in the process of angiogenesis, such as : fibroblast growth factor (FGF), angiogenin (Ang), transforming growth factor (TGF $\beta$ ), tissue factor (TF) and other [55]. In cases of many tumours, microvessel density (MVD) seems to provide a prognostic factor [55].

Tumours developing in children manifest a distinct biology than that characterizing tumours of adults. They manifest lower differentiation of cells, more intense growth and a pronounced blood supply [56] and, therefore, they are discussed separately. In many tumours of childhood, similarly as in adults, i.a. in malignant gliomas, neuromas, sarcomas, liver tumours elevated levels of VEGF are noted [62]. Also, an increased expression is noted of bFGF, angiopoetin, PDGF-A in embryonal neuromas [21] and of hepatocyte growth factor (HGF) in nephroblastoma [83]. Elevated levels of pro-angiogenic factors and of VEGF in particular represent an unfavourable prognostic factor [47]. 


\section{ANGIOGENESIS IN LYMPHOPROLIFERATIVE TUMOURS}

In 1994 the study of Vacca's team was published, demonstrating a relationship between progression of multiple myeloma (MM) and intensified develoment of new blood vessels in bone marrow [94]. The observations as well as later reports of the team [93] provided a starting point for studies on angiogenesis in proliferative diseases in haemopoetic system. Subsequent studies brought confirmation of angiogenesis development in tumours of the type [1, 28]. The observations of many research teams pertained to adults and children, in whom haematological tumours represent in the period of life the most frequent group of tumours [70].

The intensified angiogenesis in haemopoetic tumours is manifested, first of all, by augmented number of blood vessels in bone marrow, as observed for the fisrt time by Perez-Atayde in 1997 [65] in children with acute lymphoblastic leukemia, and which was later confirmed by other investigators [68, 60]. Moreover, an increased production is also noted of pro-angiogenic factors (an intensified expression of genes and proteins) both in tumour cells and endothelial cells and cells of bone marrow stroma. This is expressed by elevated levels of angiogenesis stimulators in body fluids [4, 99]. A decisive majority of such astudies pertain to leukemias, representing the most frequent type of haematologic tumours.

Thus, angiogenesis seems to form a fraction of the pathomechanism leading to lymphoproliferative tumours. However, while the cause for development of new blood vessels seems clear in solid tumours, in haematological hyperplasia determination of angiogenesis role poses an enigma. Few hypotheses attempt to clarify the matter. One of them assumes that a number of auto- and paracrine loops links cells of bone marrow stroma (also endothelial cells) with tumour cells, stimulating growth and proliferation of the two types of cells (Figure 5) [39]. It is suggested also that the newly formed blood vessels of bone marrow undergoing no destruction during chemotherapy provide a type of niche in which tumour cells find a shelter. In parallel, they provide factors of a paracrine type, which allow for growth of the ,saved” cells [72]. 


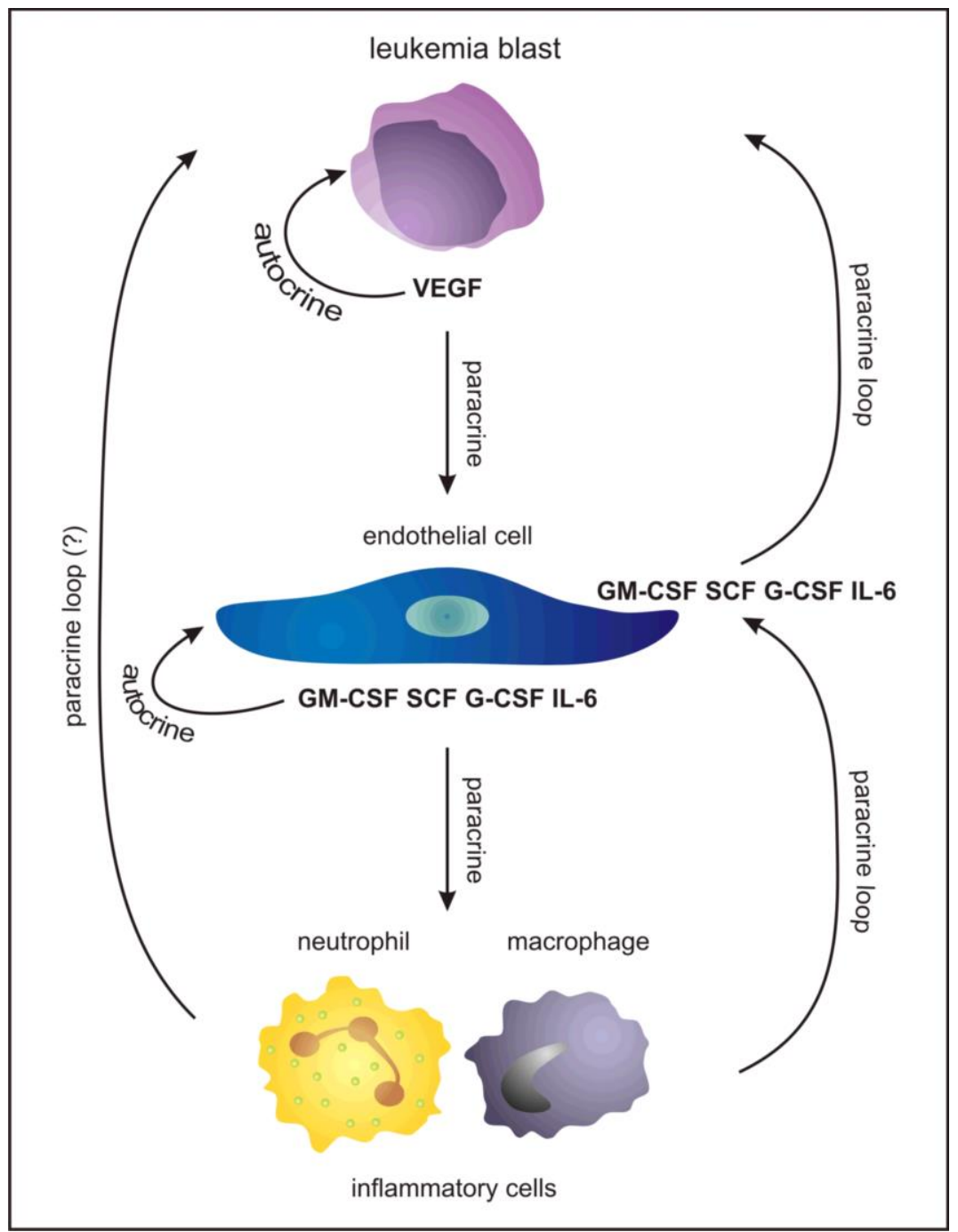

FIGURE 5. The model of auto- and paracrine loops between different cell types in bone marrow.

\section{ANGIOGENESIS AND ACUTE LYMPHOBLASTIC LEUKEMIA}

Studies on potential involvement of angiogenesis in pathophysiology of haemopoetic tumours pertain to a significant extent to acute lymphoblastic leukemia in children. Investigations using immunohistochemical techniques demonstrated stimulated formation of blood vessels in bone marrow of ALL 
children already at the moment of diagnosis $[65,68,60]$. Interestingly, the reports related to the number of blood vessel densities in bone marrrow during remission are contradictory: some investigators detected their decrease [68], while other authors detected no differences [65]. However, such a measurement of MVD manifested no prognostic value: only Norén-Nyström observed that a high proportion of blood vessels in bone marrow may be treated as a factor predisposing to relapse and only in patients qualified to the group of a high risk [60]. A decisive majority of reports related to angiogenesis in ALL analyzed expression of neovascularization-stimulating factors. Evaluation of the factor concentrations, both at the mRNA and protein levels, provides an indirect proof for significance of the process. The experiments are focused mainly on principal controllers of angiogenesis: VEGF and bFGF. Studies are available which demonstrated an elevated level of bFGF in body fluids of children with ALL, as compared to a control group [65, 50], but other reports denied such as effect [99, 78, 87]. A similar situation can be noted in the case of vascular endothelial growth factor. Numerous reports documented an elevated level of VEGF protein and an augmented expression of the gene, demonstrating also a prognoistic significance of the variable [42, 78, 4, 50, 87]. Nevertheless, some authors failed to observe an increased production of VEGF [99]. An increased expression of other proangiogenic factors was also observed, such as TGF $\beta$ [87] and receptor 3 of VEGF [40]. Discrepancies between the obtained results are explained by distinct techniques of measurement and inhomogeneity of studied groups. Thus, beyond doubt, discrepancies in the results point to the need of a continuing monitoring of angiogenesis in acute lymphoblastic leukemia.

\section{ANGIOGENESIS AND ACUTE MYELOID LEUKEMIA}

Literature reports suggest also a relationship between vasculogenesis and pathogenesis of acute myeloid leukemia (AML). Aguayo et al. [3] observed an increased number of blood vessels in bone marrow, i.a., in patients with AML. The team detected also elevated levels of pro-angiogenic type factors (VEGF, bFGF, HGF, TNF $\alpha$ ) in sera of AML patients, as compared to the control. The team of Hussong et al. [37] confirmed the reports. The investigators, using endothelial markers, including von Willebrand's factor, evaluated blood vessel density in bone marrow of adult patients with AML and control patients and found their significantly higher number in AML. They detected also expression of VEGF in cells originating from patients with AML and in cell lines of acute myeloid leukemia. Elevated numbers of blood vessels in bone marrow were detected also by Padro et al., [63]. Interestingly, they observed a reduction in number of capillaries in the course of chemotherapy: in the 16th day after induction chemotherapy MVD was reduced by $60 \%$, and in patients at remission vascular 
density reached the level noted in the control group. In acute myeloid leukemia not only an augmented angiogenesis is noted in bone marrow and an elevated level of angiogenesis stimulators but also their prognostic value is seen in AML patients. de Bont et al. [19] observed VEGF production by leukaemic cells and proved that its level in the group of high risk AML manifested a relationship with survival time and that the variable may serve as an independent prognostic factor. In turn, Hu et al. [35] found that levels of the soluble forms of VEGF receptor 1 carries a prognostic significance. Moreover, it was found that evaluation of microvessels using magnetic resonance may prove extremely helpful in determination of prognosis for a patient, suggesting that an augmented number of blood vessels in bone marrow represents an unfavourable prognostic factor [81]. The observations clearly point to formation of new blood vessels in bone marrow of AML patients and suggest an involvement of angiogenesis in development of the disease.

\section{ANGIOGENESIS IN HAEMATOLOGIC MALIGNANCIES: CLINICAL SIGNIFICANCE}

In recent years, physicians in charge of patients carrying haematologic tumours encounter the basic dilemma of how to qualify patients to individual risk groups and how to conduct treatment in patients manifesting an unfavourable course of the disease [manifesting, e.g., resistance to steroid drugs, delayed remission or relapse of the disease]. In several situations, therapeutic management is based on variables accepted by specific medical community therapeutic protocols. Nevertheless, in a certain group of patients employment of the corroborated therapeutic protocols proves to be insufficient. Such patients require a much more individualized treatment and monitoring of its effects. Current status of the therapy leads to the situation that a patient with relapse of the disease is subjected to consecutive new chemotherapy schedules (including transplantation of haemopoetic cells), which inevitably leads to progressive cachexia and an increased propensity to potentially lethal infectious agents.

Could such a status be altered? The most desirable element of therapeutic individualization in such cases seems to involve not exacerbation of the applied therapeutic protocols but attempts to target chemotherapy, basing first of all on knowledge of tumour biology. Such a type of treatment finds nowadays a restricted application. It takes into account, first of all, evaluation of tumour cell sensitivity to various chemotherapeutic agents and attempts to apply therapy using antibodies, which selectively destroy specific population of tumour cells. The commendable but solitary exception in such actions is application of drugs which block translation in patients with $t(9: 22)$ translocation (Philadelphia chromosome).

Not much can be cited on practical aspects of applying drugs which block neoplastic angiogenesis in lymphoproliferative diseases. Although the problem is 
not new, it is difficult to encounter examples of generally accepted therapeutic protocols which apply anti-angiogenic drugs in patients with therapeutic failure. The principal cause for such a status is not the fear of undesirable side effects of angiogenesis-blocking drugs, but absence if a sufficient proof for involvement of pro-angiogenic factors in pathogenesis of lymphoproliferative diseases.

Biology of lymphoproliferative tumours continues to pose a puzzle. In contrast to solid tumours, in which neoangiogenesis remains fully logical and understandable, development of new blood vessels in haematologic tumours remains a matter of conjectures and assumptions. The question arises of how to explain the need for development of the blood vessels in tumours of haemopoetic system, when the tumour itself develops in the biotope of bone marrow or in the site of blood formation. Certainly, the process of developing new blood vessels is not needed to supply the proliferating neoplastic cells with nutrients, oxygen or factors stimulating their growth. This factor is also indicated by the clinical course in this group of tumours: no primary tumour can be detected and the disease is primarily of a diffuse character. In addition, in bone marrow neoplastic cells enjoy a permanent and an easy access to already existing blood vessels in sinusoidal compartment of bone marrow.

Nevertheless, which surprised investigators already in 1990-ties, also haematologic tumours, including acute lymphoblastic leukemia and acute nyeloid leukemia, manifest an increased number of blood vessels in bone marrow and elevated serum levels of several pro-angiogenic factors. The question which can be posed at this moment is whether this is a purposeful action in the course of the diseases or, perhaps, tumour cells, copying behaviour of other tumour cells in solid tumours, begin to produce blood vessels without the intention to use them. Solution of such a problem seems complex: first, in no tumour purposeful actions can be encountered, which would reflect optimum use of energy and available components, as it can be observed in a healthy tissue. A tumour represents a chaos, the principal effect of which involves destabilization of existing structures and relationships. Against such a background, development of new blood vessels in a haematologic tumour may be treated as a clear accident. An accident which, however, does not remain without lethal consequences: the newly formed blood vessels, possibly made of neoplastic cells themselves, are not destroyed in the course of pharmacotherapy. It suggests that they might create a specific niche, a reservoir for blasts, located beyond the reach of the applied chemotherapeutic drugs [72]. In parallel, apart from the undoubtful benefit of the shelter, tumour cells obtain an additional source of growth factors: endothelial cells begin to produce substances which stimulate growth, differentiation and proliferation . It should be mentioned that blood vessels synthesize also angiogenesis regulators, factors of stimulator and inhibitor types, which represents their de facto natural function, intensified in neoplastic diseases. In parallel, in line with the theory related to cancerogenesis-associated angiogenesis, also tumour cells are responsible for production of pro-angiogenic factors. In cases of lymphoproliferation, the 
producers include also stromal cells of bone marrow. The facts permitted to construct a model demonstrating amngiogenesis-linked relationships between various cell populations in haematologic tumours. Function of several auto- and paracrine loops is postulated, produced and acting on the above cell types. Such events result in development of a microenvironment in bone marrow which is rich in newly formed blood vessels, which promotes tumour development [39]. As it was already mentioned, neoangiogenesis in lymphoproliferative tumours manifests not only elevated number of blood vessels in bone marrow but also increased concentrations of angiogenesis-stimulating factors in body fluids [65, 4]. Aguayo et al. [3] demonstrated, among other, an increased concentration of VEGF in bone marrow and peripheral blood which represented an independent prognostic factor in patients with acute myeloid leukemia. Similar results were obtained by Avramis et al., [4] who showed that not only high level of VEGF in serum could be noted in children with ALL who suffered from a relapse of the disease, but in addition it manifested negative correlation with timing of the relapse. The data were confirmed by the team of Lyu [50], who observed a significantly higher levels of VEGF and fibroblast growth factor in children with acute leukemia. Investigations determining concentrations of angiogenesis regulators also belong to the molecular aspects. Koomagi et al. [42] noted elevated levels of mRNA coding for vascular endothelial growth factor during relapose of ALL, which was corroborated later by Stachel et al. [87]. Moreover, duration of relapse-free survival and total survival time manifested a negative correlation with VEGF concentration. Obviously, the most reliable method determining intensity of angiogenesis involves a direct estimation of microvessel density in bole marrow. Already the last 1990-ties brought information on augmented microvessel density in bone marrow of patients with acute leukemia [65,37]. The elevated MVD was found to be linked to prognosis of unfavourable events in the course of ALL, such as relapse or death [60]. Against this backgroud, it seems justified to monitor indirect (expression of pro- and anti-angiogenic factors) and direct (MVD in bone marrow) parameters of neovascularization, aimed at attempting to modify therapeutic management of patients with haematologic tumours.

The problem of angiogenesis in hyperplasias of haemopoetic system is relatively new: the first reports originated from mid 1990-ties. The studies were focused mainly on evaluation of expression shown by principal regulators of angiogenesis, the VEGF family, seldom encompassing evaluation of other factors, the role of which in this type of tumours can be far greater. The very term of „haematologic tumours" is extremely broad, including tumours originating from various cell types of an acute or a chronic course. It should also be born in mind that biology of the diseases differs markedly between adults and children. Difficulties originate also from contradictory reports and absence of knowledge related to function of various factors. Therefore, studies on angiogenesis in haematologic tumours seem to be immensely interesting from both the clinical and the cognitive point of view. 


\section{ACKNOWLEDGEMENT}

This work was supported by the Polish Ministry of Sciences and Higher Education (grant number 0059/B/P01/2008/35).

\section{REFERENCES}

[1] ABOUDOLA S, KINI AR.2. Angiogenessis in lymphoproliferative disorders:-_a therapeneutic targetet? Curr Opin Hematol 2005; 12(4): 279-83.

[2] ACHEN MG, GAD JM, STACKER SA, WILKS AF. Plaçenta growth factor and vascular endothelial growth factor are co-expressed during early embryonic development. Growth Factors 1997; 15(1): 6980 .

[3] AGUAYO A, KANTARJIAN H, MANSHOURI T, GIDEL C, ESTEY E, THOMAS D, KOLLER C, ESTROV Z, O'BRIEN S, KEATING M, FREIREICH E, ALBITAR M. Angiogenesis in acute and chronic leukemias and myelodysplastic syndromes. Blood 2000; 96(6): 2240-2245.

[4] AVRAMIS IA, PANOSYAN EH, DOREY F, HOLCENBERG JS, AVRAMIS VI. Children's Oncology Group., Correlation between high vascular endothelial growth factor-A serum levels and treatment outcome in patients with standard-risk acute lymphoblastic leukemia: a report from Children's Oncology Group Study CCG-1962. Clin Cancer Res 2006; 12(23): 6978-6984.

[5] BACHELDER RE, CRAGO A, CHUNG J, WENDT MA, SHAW LM, ROBINSON G, MERCURIO AM. Vascular endothelial growth factor is an autocrine survival factor for neuropilin-expressing breast carcinoma cells. Cancer Res 2001; 61(15): 5736-5740.

[6] BATES DO, HILLMAN NJ, WILLIAMS B, NEAL CR, POCOCK TM. Regulation of microvascular. permeability by vascular endothelial growth factors. J Anat 2002; (6): 581-97.

[7] BATTEGAY EJ. Angiogenesis: mechanistic insights, neovascular diseases, and therapeutic prospects. J Mol Med 1995; 73(7): 333-346.

[8] BELLÓN T, CORBí A, LASTRES P, CALÉS C, CEBRIÁN M, VERA S, CHEIFETZ S, MASSAGUE J, LETARTE M, BERNABÉU C. Identification and expression of two forms of the. human transforming growth factor-beta-binding protein endoglin with distinct cytoplasmic regions. Eur J Immunol 1993; 23(9): 2340-2345.

[9] BENJAMIN LE, KESHET E. Conditional switching of vascular endothelial growth factor (VEGF) expression in tumors: induction of endothelial cell shedding and regression of hemangioblastoma-like vessels by VEGF withdrawal. Proc Natl Acad Sci USA 1997; 94(16): 8761-8766

[10] BOGAR LJ, BARTULA LL, PARKMAN HP, MYERS SI. Enhanced bradykinin-stimulated prostaglandin release in the acutely inflamed guinea pig gallbladder is due to new synthesis of cyclooxygenase 1 and prostacyclin synthase. J Surg Res 1999; 84(1): 71-76.

[11] BOULOUMIÉ A, DREXLER HC, LAFONTAN M, BUSSE R. Leptin, the product of Ob gene, promotes angiogenesis. Circ Res 1998; 83(10): 1059-1066.

[12] BREIER G. Angiogenesis in embryonic development--a review. Placenta 2000; 21 Suppl A: S11-15.

[13] BROOKS PC, STRÖMBLAD S, KLEMKE R, VISSCHER D, SARKAR FH, CHERESH DA. Antiintegrin alpha v beta 3 blocks human breast cancer growth and angiogenesis in human skin. J Clin Invest 1995; 96(4): 1815-1822.

[14] CARMELIET P. Angiogenesis in health and disease. Nat Med 2003; 9(6): 653-660

[15] CARMELIET P, JAIN RK. Angiogenesis in cancer and other diseases. Nature 2000; 407(6801): 249257.

[16] CARMELIET P, MOONS L, LUTTUN A, VINCENTI V, COMPERNOLLE V, DE MOL M, WU Y, BONO F, DEVY L, BECK H, SCHOLZ D, ACKER T, DIPALMA T, DEWERCHIN M, NOEL A, STALMANS I, BARRA A, BLACHER S, VANDENDRIESSCHE T, PONTEN A, ERIKSSON U, PLATE KH, FOIDART JM, SCHAPER W, CHARNOCK-JONES DS, HICKLIN DJ, HERBERT JM, COLLEN D, PERSICO MG. Synergism between vascular endothelial growth factor and placental 
growth factor contributes to angiogenesis and plasma extravasation in pathological conditions. Nat Med 2001; 7(5): 575-583.

[17] CHEIFETZ S, BELLÓN T, CALÉS C, VERA S, BERNABEU C, MASSAGUÉ J, LETARTE M. Endoglin is a component of the transforming growth factor-beta receptor system in human endothelial cells. J Biol Chem 1992; 267(27): 19027-19030.

[18] DALLAS NA, SAMUEL S, XIA L, FAN F, GRAY MJ, LIM SJ, ELLIS LM, Endoglin (CD105): a marker of tumor vasculature and potential target for therapy. Clin Cancer Res 2008; 14(7): 1931-1937.

[19] DE BONT ES, NEEFJES VM, ROSATI S, VELLENGA E, KAMPS WA. New vessel formation and aberrant VEGF/VEGFR signaling in acute leukemia: does it matter? Leuk Lymphoma 2002; 43(10): $1901-1909$.

[20] DÜWEL A, ELENO N, JERKIC M, AREVALO M, BOLAÑOS JP, BERNABEU C, LÓPEZNOVOA JM, Reduced tumor growth and angiogenesis in endoglin-haploinsufficient mice. Tumour Biol 2007; 28(1): 1-8.

[21] EGGERT A, IKEGAKI N, KWIATKOWSKI J, ZHAO H, BRODEUR GM, HIMELSTEIN BP, Highlevel expression of angiogenic factors is associated with advanced tumor stage in human neuroblastomas. Clin Cancer Res 2000; 6(5): 1900-1908.

[22] ELICEIRI BP, CHERESH DA. The role of alphav integrins during angiogenesis: insights into potential mechanisms of action and clinical development. J Clin Invest 1999; 103(9): 1227-1230.

[23] FERRARA N, GERBER HP, LECOUTER J. The biology of VEGF and its receptors. Nat Med 2003; 9(6): 669-676

[24] FOLKMAN J. Angiogenesis in cancer, vascular, rheumatoid and other disease. Nat Med 1995; 1(1): 27-31

[25] FOLKMAN J. Tumor angiogenesis. Adv Cancer Res 1985; 43: 175-203.

[26] FONSATTI E, DEL VECCHIO L, ALTOMONTE M, SIGALOTTI L, NICOTRA MR, CORAL S, NATALI PG, MAIO M. Endoglin: An accessory component of the TGF-beta-binding receptorcomplex with diagnostic, prognostic, and bioimmunotherapeutic potential in human malignancies. J Cell Physiol 2001; 188(1): 1-7.

[27] FONSATTI E, JEKUNEN AP, KAIREMO KJ, CORAL S, SNELLMAN M, NICOTRA MR, NATALI PG, ALTOMONTE M, MAIO M. Endoglin is a suitable target for efficient imaging of solid tumors: in vivo evidence in a canine mammary carcinoma model. Clin Cancer Res 2000; 6(5): 20372043.

[28] FOSS HD, ARAUJO I, DEMEL G, KLOTZBACH H, HUMMEL M, STEIN H. Expression of vascular endothelial growth factor in lymphomas and Castleman's disease. J Pathol 1997; 183(1): 4450 .

[29] GERBER HP, VU TH, RYAN AM, KOWALSKI J, WERB Z. FERRARA N. VEGF couples hypertrophic cartilage remodeling, ossification and angiogenesis during endochondral bone formation. Nat Med 1999; 5(6): 623-628.

[30] GOUGOS A, LETARTE M. Identification of a human endothelial cell antigen with monoclonal antibody 44G4 produced against a pre-B leukemic cell line. J Immunol 1988; 141(6): 1925-1933.

[31] GOUMANS MJ, LIU Z, TEN DIJKE P. TGF-beta signaling in vascular biology and dysfunction. Cell Res 2009; 19(1): 116-127.

[32] GUERRERO-ESTEO M, SANCHEZ-ELSNER T, LETAMENDIA A, BERNABEU C. Extracellular and cytoplasmic domains of endoglin interact with the transforming growth factor-beta receptors I and II. J Biol Chem 2002; 277(32): 29197-29209.

[33] HANAHAN D, FOLKMAN J. Patterns and emerging mechanisms of the angiogenic switch during tumorigenesis. Cell 1996; 86(3): 353-364

[34] HOOD JD, MEININGER CJ, ZICHE M, GRANGER HJ. VEGF upregulates ecNOS message, protein, and NO production in human endothelial cells. Am J Physiol 1998; 274(3 Pt 2): H1054-1058

[35] HU Q, DEY AL, YANG Y, SHEN Y, JILANI IB, ESTEY EH, KANTARJIAN HM, GILES FJ, ALBITAR M. Soluble vascular endothelial growth factor receptor 1, and not receptor 2, is an independent prognostic factor in acute myeloid leukemia and myelodysplastic syndromes. Cancer 2004; 100(9): 1884-1891.

[36] HURWITZ H, FEHRENBACHER L, NOVOTNY W, CARTWRIGHT T, HAINSWORTH J, HEIM W, BERLIN J, BARON A, GRIFFING S, HOLMGREN E, FERRARA N, FYFE G, ROGERS B, 
ROSS R, KABBINAVAR F. Bevacizumab plus irinotecan, fluorouracil, and leucovorin for metastatic colorectal cancer. N Engl J Med 2004; 350(23): 2335-2342.

[37] HUSSONG JW, RODGERS GM, SHAMI PJ. Evidence of increased angiogenesis in patients with acute myeloid leukemia. Blood 2000; 95(1): 309-313.

[38] JERKIC M, RIVAS-ELENA JV, PRIETO M, CARRÓN R, SANZ-RODRÍGUEZ F, PÉREZBARRIOCANAL F, RODRÍGUEZ-BARBERO A, BERNABÉU C, LÓPEZ-NOVOA JM. Endoglin regulates nitric oxide-dependent vasodilatation. FASEB J 2004; 18(3): 609-611.

[39] KEYHANI A, JENDIROBA DB, FREIREICH EJ. Angiogenenesis and leukeminia. Leuk Res 2001; 25(8): 639-645.

[40] KIVIVUORI SM, SIITONEN S, PORKKA K, VETTENRANTA K, ALITALO R, SAARINENPIHKALA U. Expression of vascular endothelial growth factor receptor 3 and Tie1 tyrosine kinase receptor on acute leukemia cells. Pediatr Blood Cancer 2007; 48(4): 387-392.

[41] KOERSELMAN J, VAN DER GRAAF Y, DE JAEGERE PP, GROBBEE DE, Coronary collaterals: an important and underexposed aspect of coronary artery disease. Circulation 2003; 107(19): 25072511.

[42] KOOMAGI R, ZINTL F, SAUERBREY A, VOLM M. Vascular endothelial growth factor in newly diagnosed and recurrent childhood acute lymphoblastic leukemia as measured by real-time quantitative polymerase chain reaction. Clin Cancer Res 2001; 7(11): 3381-3384.

[43] KUMAR S, GHELLAL A, LI C, BYRNE G, HABOUBI N, WANH JM, BUNDRED N. Breast carcinoma: vascular density determined using CD105 antibody correlates with tumor prognosis. Cancer Res 1999; 59(4): 856-861

[44] LI C, ISSA R, KUMAR P, HAMPSON IN, LOPEZ-NOVOA JM, BERNABEU C, KUMAR S. CD105 prevents apoptosis in hypoxic endothelial cells. J Cell Sci 2003; 116 (Pt 13): 2677-2685.

[45] LI DY, SORENSEN LK, BROOKE BS, URNESS LD, DAVIS EC, TAYLOR DG, BOAK BB, WENDEL DP. Defective angiogenesis in mice lacking endoglin. Science 1999; 284(5419): 15341537.

[46] LI W, JI ZL, ZHUO GC, XU RJ, WANG J, JIANG HR. Effects of a selective cyclooxygenase-1 inhibitor in SKOV-3 ovarian carcinoma xenograft-bearing mice. Med Oncol 2010; 27(1): 98-104

[47] LIN RY, ARGENTA PA, SULLIVAN KM, ADZICK NS. Diagnostic and prognostic role of basic fibroblast growth factor in Wilms' tumor patients. Clin Cancer Res 1995; 1(3): 327-331.

[48] LIU Y, JOVANOVIC B, PINS M, LEE C, BERGAN RC. Over expression of endoglin in human. prostate cancer suppresses cell detachment, migration and invasion. Oncogene $2002 ; 21(54)$ : 8272 8281.

[49] LUTTUN A, BRUSSELMANS K, FUKAO H. TJWA M, UESHIMA S, HERBERT JM, MATSUO O, COLLEN D, CARMELIET P, MOONS L. Loss of placental growth factor protects mice against vascular permeability in pathological conditions. Biochem Biophys Res Commun 2002; 295(2): 428434

[50] LYU CJ, RHA SY, WON SC. Clinical role of bone marrow angiogenesis in childhood acute lymphocytic leukemia. Yonsei Med J 2007; 48(2): 171-175.

[51] MAEDA K, CHUNG YS, OGAWA Y, TAKATSUKA S, KANG SM, OGAWA M, SAWADA T, SOWA M. Prognostic value of vascular. endothelial growth factor expression in gastric carcininoma. Cancer 1996; 77(5): 858-863.

[52] MAGLIONE D, GUERRIERO V, VIGLIETTO G, DELLI-BOVI P, PERSICO MG. Isolation of a human placenta cDNA coding for a protein related to the vascular permeability factor. Proc Natl Acad Sci U S A 1991; 88(20): 9267-9271.

[53] MAGLIONE D, GUERRIERO V, VIGLIETTO G, FERRARO MG, APRELIKOVA O, ALITALO K, DEL VECCHIO S, LEI KJ, CHOU JY, PERSICO M.G. Two alternative mRNAs coding for the angiogenic factor, placenta growth factor (PIGF), are transcribed from a single gene of chromosome 14. Oncogene 1993; 8(4): 925-931.

[54] MAISONPIERRE PC, SURI C, JONES PF, BARTUNKOVA S, WIEGAND SJ, RADZIEJEWSKI C, COMPTON D, MCCLAIN J, ALDRICH TH, PAPADOPOULOS N, DALY TJ, DAVIS S, SATO TN, YANCOPOULOS GD. Angiopoietin-2, a natural antagonist for Tie2 that disrupts in vivo angiogenesis. Science 1997; 277(5322): 55-60.

[55] MAKRILIA N, LAPPA T, XYLA V, NIKOLAIDIS I, SYRIGOS K. The role of angiogenesis in solid tumours: an overview. Eur J Intern Med 2009; 20(7): 663-671 
[56] MIZIA-MALARZ A, SOBOL G, WOŚ H. Angiogeneza w przewlekłych schorzeniach zapalnych i nowotworowych. Pol Merk Lek 2008; XXIV, 141: 185-189

[57] MURAKAMI M, MATSUMOTO R, URADE Y, AUSTEN KF, ARM JP. c-kit ligand mediates increased expression of cytosolic phospholipase A2, prostaglandin endoperoxide synthase-1, and hematopoietic prostaglandin D2 synthase and increased IgE-dependent prostaglandin D2 generation in immature mouse mast cells. J Biol Chem 1995; 270(7): 3239-3246.

[58] MURPHY JF, FITZGERALD DJ. Vascular endothelial growth factor induces cyclooxygenasedependent proliferation of endothelial cells via the VEGF-2 receptor. FASEB J 2001; 15(9): 16671669.

[59] NACOV E. Tumor angiogenesis formation of vessels de novo at germ cell tumors. Cancer 1990; 66(5): 916-922.

[60] NORÉN-NYSTRÖM U, HEYMAN M, FRISK P, GOLOVLEVA I, SUNDSTRÖM C, PORWIT A, ROOS G, BERGH A, FORESTIER E. Vascular density in childhood acute lymphoblastic leukemia correlates to biological factors and outcome. Br J Haematol 2009; 146(5): 521-530

[61] OXMANN D, HELD-FEINDT J, STARK AM, HATTERMANN K, YONEDA T, MENTLEIN R. Endoglin expression in metastatic breast cancer cells enhances their invasive phenotype. Oncogene 2008; 27(25): 3567-3575.

[62] OZER E, SARIALIOGLU F, CETINGOZ R, YÜCEER N, CAKMAKCI H, OZKAL S, OLGUN N, UYSAL K, CORAPCIOGLU F, CANDA S. Prognostic significance of anaplasia and angiogenesis in childhood medulloblastoma: a pediatric oncology group study. Pathol Res Pract 2004; 200 (7-8): 501509.

[63] PADRO T, RUIZ S, BIEKER R, BÜRGER H, STEINS M, KIENAST J, BÜCHNER T, BERDEL WE, MESTERS RM. Increased angiogenesis in the bone marrow of patients with acute myeloid leukemia. Blood 2000; 95: 2637-2644.

[64] PEPPER MS, FERRARA N, ORCI L, MONTESANO R. Vascular endothelial growth factor (VEGF) induces plasminogen activators and plasminogen activator inhibitor-1 in microvascular endothelial cells. Biochem Biophys Res Commun 1991 Dec 16; 181(2): 902-906

[65] PEREZ-ATAYDE AR, SALLAN SE, TEDROW U, CONNORS S, ALLRED E, FOLKMAN J. Spectrum of tumor angiogenesis in the bone marrow of children with acute lymphoblastic leukemia Am J Pathol 1997; 150(3): 815-821.

[66] PERSICO MG, VINCENTI V, DIPALMA T. Structure, expression and receptor-binding properties of placenta growth factor (PIGF). Curr Top Microbiol Immunol 1999; 237: 31-40.

[67] PRICE DJ, MIRALEM T, JIANG S, STEINBERG R, AVRAHAM H. Role of vascular endothelia growth factor in the stimulation of cellular invasion and signaling of breast cancer cells. Cell Growth Differ 2001; 12(3): 129-135.

[68] PULE MA, GULLMANN C, DENNIS D, MCMAHON C, JEFFERS M, SMITH OP. Increased angiogenesis in bone marrow of children with acute lymphoblastic leukemia has no prognostic significance. Br J Haematol 2002; 118(4): 991-998.

[69] QU R, SILVER MM, LETARTE M. Distribution of endoglin in early human development reveals high levels on endocardial cushion tissue mesenchyme during valve formation. Cell Tissue Res 1998; 292(2): 333-343.

[70] RADWAŃSKA U [red.] Białaczki u dzieci. Volumed, Wrocław ,1998: 17-89

[71] RAK J, FILMUS J, KERBEL RS. Reciprocal paracrine interactions between tumour cells and endothelial cells: the 'angiogenesis progression' hypothesis. Eur J Cancer 1996; 32A(14): 2438-2450.

[72] RATAJCZAK MZ, RATAJCZAK J, MACHALINSKI B, MAJKA M, MARLICZ W, CARTER A, PIETRZKOWSKI Z, GEWIRTZ AM. Role of vascular endothelial growth factor (VEGF) and placenta-derived growth factor (PlGF) in regulating human haemopoietic cell growth. $\mathrm{Br} \mathrm{J}$ Haematol 1998; 103(4): 969-979.

[73] RISAU W, FLAMME I. Vaㅗㄷulogenenesis. Annu Rev Cell Dev Biol 1995; 11: 73-91.

[74] RISTIMÄKI A, NARKO K, ENHOLM B, JOUKOV V, ALITALO K. Proinflammatory cytokines regulate expression of the lymphatic endothelial mitogen vascular endothelial growth factor-C. J Biol Chem 1998; 273(14): 8413-8418

[75] SALES KJ, KATZ AA, HOWARD B, SOETERS RP, MILLAR RP, JABBOUR HN Cyclooxygenase-1 is up-regulated in cervical carcinomas: autocrine/paracrine regulation of 
cyclooxygenase-2, prostaglandin e receptors, and angiogenic factors by cyclooxygenase-1. Cancer Res 2002; 62(2): 424-432

[76] SANO H, NOGUCHI T, MIYAJIMA A, HASHIMOTO Y, MIYACHI H. Anti-angiogenic activity of basic-type, selective cyclooxygenase (COX)-1 inhibitors. Bioorg Med Chem Lett 2006; 16(11): 30683072

[77] SATO N, BEITZ JG, KATO J, YAMAMOTO M, CLARK JW, CALABRESI P, RAYMOND A, FRACKELTON AR JR. Platelet-derived growth factor indirectly stimulates angiogenesis in vitro. Am J Pathol 1993;142(4):1119-1130.

[78] SCHNEIDER N, LANZ S, RAMER R, SCHAEFER D, GOPPELT-STRUEBE M. Up-regulation of cyclooxygenase-1 in neuroblastoma cell lines by retinoic acid and corticosteroids. J Neurochem 2001; 77(2): 416-424.

[79] SENGER DR, GALLI SJ, DVORAK AM, PERRUZZI CA, HARVEY VS, DVORAK HF. Tumor cells secrete a vascular permeability factor that promotes accumulation of ascites fluid. Science 1983; 25;219(4587): 983-985.

[80] SEO Y, BABA H, FUKUDA T, TAKASHIMA M, SUGIMACHI K. High expression of vascular endothelial growth factor is associated with liver metastasis and a poor prognosis for patients with ductal pancreatic adenocarcinoma. Cancer 2000; $88(10): 2239-2245$.

[81] SHIH TT, HOU HA, LIU CY, CHEN BB, TANG JL, CHEN HY, WEI SY, YAO M, HUANG SY, CHOU WC, HSU SC, TSAY W, YU CW, HSU CY, TIEN HF, YANG PC. Bone marrow. angiogenesis magnetic resonance imaging in patients with acute myeloid leukemia: peak enhancement ratio is an independent predictor for overall survival. Blood 2009; 113(14): 3161-7.

[82] SIEGFRIED G, BASAK A, CROMLISH JA, BENJANNET S, MARCINKIEWICZ J, CHRÉTIEN M, SEIDAH NG, KHATIB AM. The secretory proprotein convertases furin, PC5, and PC7 activate VEGF-C to induce tumorigenesis. J Clin Invest 2003; 111(11): 1723-1732

[83] SKÖLDENBERG EG, CHRISTIANSSON J, SANDSTEDT B, LARSSON A, LÄCKGREN G, CHRISTOFFERSON R. Angiogenesis and angiogenic growth factors in Wilms tumor. J Urol 2001; 165 (6 Pt 2): 2274-2279.

[84] SKÓRA J, BIEGUS J, PUPKA A, BARĆ P, SIKORA J, SZYBER P. Molekularne podstawy angiogenezy. Postepy Hig Med Dosw. (online), 2006; 60: 410-415

[85] SMITH SK. Angiogenesis and implantation. Hum Reprod 2000; 15 Suppl 6: 59-66.

[86] SMITH WL, DEWITT DL, GARAVITO RM. Cyclooxygenases: structural, cellular, and molecular biology. Annu Rev Biochem 2000; 69: 145-182.

[87] STACHEL D, ALBERT M, MEILBECK R, PAULIDES M, SCHMID I. Expression of angiogenic factors in childhood B-cell precursor acute lymphoblastic leukemia. Oncol Rep 2007; 17(1): 147-152.

[88] STEWART M, TURLEY H, COOK N, PEZZELLA F, PILLAI G, OGILVIE D, CARTLIDGE S, PATERSON D, COPLEY C, KENDREW J, BARNES C, HARRIS AL, GATTER KC. The angiogenic receptor KDR is widely distributed in human tissues and tumours and relocates intracellularly on phosphorylation. An immunohistochemical study. Histopathology 2003; 43(1): 33 39.

[89] ST-JACQUES S, FORTE M, LYE SJ, LETARTE M. Localization of endoglin, a transforming growth factor-beta binding protein, and of CD44 and integrins in placenta during the first trimester of pregnancy. Biol Reprod 1994; 51(3): 405-413.

[90] TAMMELA T, ENHOLM B, ALITALO K, PAAVONEN K. The biology of vascular endothelial growth factors. Cardiovasc Res 2005; 65(3): 550-563

[91] TANABE T, TOHNAI N. Cyclooxygenase isozymes and their gene structures and expression. Prostaglandins Other Lipid Mediat 2002; 68-69: 95-114

[92] TSUJII M, KAWANO S, TSUJI S, SAWAOKA H, HORI M, DUBOIS RN. Cyclooxygenase regulates angiogenesis induced by colon cancer cells. Cell 1998; 93(5): 705-716.

[93] VACCA A, RIBATTI D, IURLARO M, ALBINI A, MINISCHETTI M, BUSSOLINO F, PELLEGRINO A, RIA R, RUSNATI M, PRESTA M, VINCENTI V, PERSICO MG, DAMMACCO F. Human lymphoblastoid cells produce extracellular matrix-degrading enzymes and induce endothelial cell proliferation, migration, morphogenesis, and angiogenesis. Int J Clin Lab Res 1998; 28(1): 55-68. 
[94] VACCA A, RIBATTI D, RONCALI L, RANIERI G, SERIO G, SILVESTRIS F, DAMMACCO F. Bone marrow angiogenesis and progression in multiple myeloma. Br J Haematol 1994; 87(3): 503508.

[95] VAN ROYEN N, PIEK JJ, SCHAPER W, BODE C, BUSCHMANN I. Arteriogenesis: mechanisms and modulation of collateral artery development. J Nucl Cardiol 2001; 8(6): 687-693.

[96] VIITA H, MARKKANEN J, ERIKSSON E, NURMINEN M, KINNUNEN K, BABU M, HEIKURA T, TURPEINEN S, LAIDINEN S, TAKALO T, YLA-HERTTUALA S. 15-lipoxygenase-1 prevents vascular endothelial growth factor A- and placental growth factorinduced angiogenic effects in rabbit skeletal muscles via reduction in growth factor mRNA levels, NO bioactivity, and downregulation of VEGF receptor 2 expression. Circ Res. 2008; 102(2): 177-184.

[97] WITTE MB, BARBUL A. General principles of wound healing. Surg Clin North Am 1997; 77(3): 509-528.

[98] XU L, COCHRAN DM, TONG RT, WINKLER F, KASHIWAGI S, JAIN RK, FUKUMURA D Placenta growth factor overexpression inhibits tumor growth, angiogenesis, and metastasis by depleting vascular endothelial growth factor homodimers in orthotopic mouse models. Cancer Res 2006; 66(8): 3971-3977.

[99] YETGIN S, YENICESU I, CETIN M, TUNCER M. Clinical importance of serum vascular endothelial and basic fibroblast growth factors in children with acute lymphoblastic leukemia. Leuk Lymphoma 2001; 42(1-2): 83-88.

[100] YOKOYAMA C, TANABE T. Cloning of human gene encoding prostaglandin endoperoxide synthase and primary structure of the enzyme. Biochem Biophys Res Commun 1989; 165(2): 888-894.

Corresponding author: Patrycja Sujka-Kordowska

Poznań Univeristy of Medical Sciences

6 Święcickiego Str., 60-781 Poznań, Poland

phone: +48618546428

e-mail:psujka@ump.edu.pl 